\title{
Reverse magnetic anomaly controlled by Permian Igneous rocks in the Iberian Chain ( $\mathrm{N}$ Spain)
}

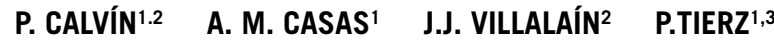 \\ 'Dpto. de Ciencias de la Tierra. Universidad de Zaragoza \\ C/Pedro Cerbuna, 12, 50009 Zaragoza, Spain. Casas E-mail: acasas@unizar.es \\ ${ }^{2}$ Dpto. de Física, Escuela Politécnica Superior, Universidad de Burgos \\ Avda. Cantabria, s/n, 09006 Burgos, Spain. Calvín E-mail: pcalvin@ubu.es Villalaín E-mail: villa@ubu.es \\ Instituto Nazionale di Geofisica e Vulcanologia, Sezione di Bologna \\ Via Donato Creti, 12, 40128 Bologna, Italy. Tierz E-mail: pablo.tierz@bo.ingv.it
}

\begin{abstract}
Two important reverse dipolar magnetic anomalies in the Iberian Chain (Spain) are located over Permian igneous rocks. A detailed study of one of them, the Loscos magnetic anomaly, where the geological structure is well constrained, reveals that the source of the anomaly must be a reverse remanent magnetisation carried by igneous rocks, acquired during the period of the Kiaman reverse magnetic superchron. Magnetic and gravimetric detailed survey (with 50 new gravimetric measurements and 8 main magnetic profiles -six of them N-S and the rest E-Wwith a total length of $40 \mathrm{~km}$ ), together with a study of the petrophysical characteristics of igneous materials, data processing and interpretation (upward continuation, 2.5D modelling, etc.) allowed to characterize qualitatively the anomaly and its source. Two overlapping anomalies with different wavelength were identified, indicating the presence of a shallower strongly altered igneous body with heterogeneous magnetic properties, and a deeper, large igneous body, responsible for the main, long-wavelength anomaly.
\end{abstract}

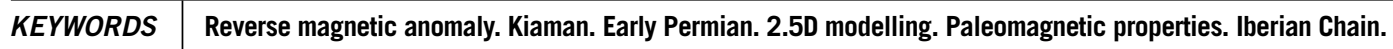

\section{INTRODUCTION}

Analyses of magnetic or aeromagnetic anomalies are an important tool to infer the presence of deep bodies whose magnetic properties contrast with those of the host rock (Kristjansson and Jonsson, 2007; Ortiz-Alemán and Urrutia-Fucugauchi, 2010; Rybakov et al., 2011; Louro and Mantovani, 2012; Urrutia-Fucugauchi et al., 2012; Ribeiro et al., 2013, among others). The aeromagnetic map of Spain (Ardizone et al., 1989; Socías and Mezcua, 2002), whose lines were measured in 1987 at an elevation of $3000 \mathrm{~m}$, shows a number of dipolar magnetic anomalies, most of them with normal polarity (or induced magnetisation), especially abundant in the western portion of the Iberian Peninsula. These anomalies are related to different geological settings, and many of them have been associated with changes in crustal thickness, the existence of igneous bodies, diapirs cored by gypsum and mafic volcanic rocks, etc. (e.g. Casas et al., 1997; Gómez-Ortiz et al., 2005; Ayarza and Martínez-Catalán, 2007; Pedreira et al., 2007; Santolaria et al., 2012; Del Río et al., 2013, among others). The Iberian Chain, occupying the eastern portion of the Iberian Peninsula, does not show prominent magnetic anomalies, because of its relatively thick sedimentary cover and the relative scarcity of igneous rocks (see e.g. Salas and Casas, 1993; De Vicente et al., 2009). However, 
several dipolar magnetic anomalies, some of them normal (Cameros Massif, CMA; Del Río et al., 2013), and two reverse (Atienza, AMA, and Loscos, LMA), with intensities in the range of 20-110nT in the aeromagnetic map, can be distinguished (Fig. 1). It is of particular interest that the two relevant reverse anomalies located in the Iberian Chain are located in two major outcrops of Lower Permian igneous rocks (Lago et al., 2004), thus allowing to hypothesize an apparent relationship between them.

The Atienza Magnetic Anomaly (AMA, Fig. 1B) is located on the western sector of the Iberian Range, near its limit with the Central System (Gibbons and Moreno, 2002; Vera, 2004) and represents a major anomaly, with an amplitude of $110 \mathrm{nT}$ (in the aeromagnetic map) and $45 \mathrm{~km}$ long in E-W direction. Volcanic rocks of Atienza have a $287 \pm 12 \mathrm{Ma}$ age (K/Ar for the whole rock; Hernando et al., 1980).

The Loscos Reverse Magnetic Anomaly (LMA, Fig. 1C), smaller in size and amplitude, is the objective of this paper. The Loscos igneous rocks have been studied by several authors (e.g. Hernando et al., 1980; López-Ciriano et al., 1997; Lago et al., 2005 and references therein). However, the magnetic anomaly presumably generated by these rocks has not been studied yet in detail. In this paper, favoured by a very detailed structural control of

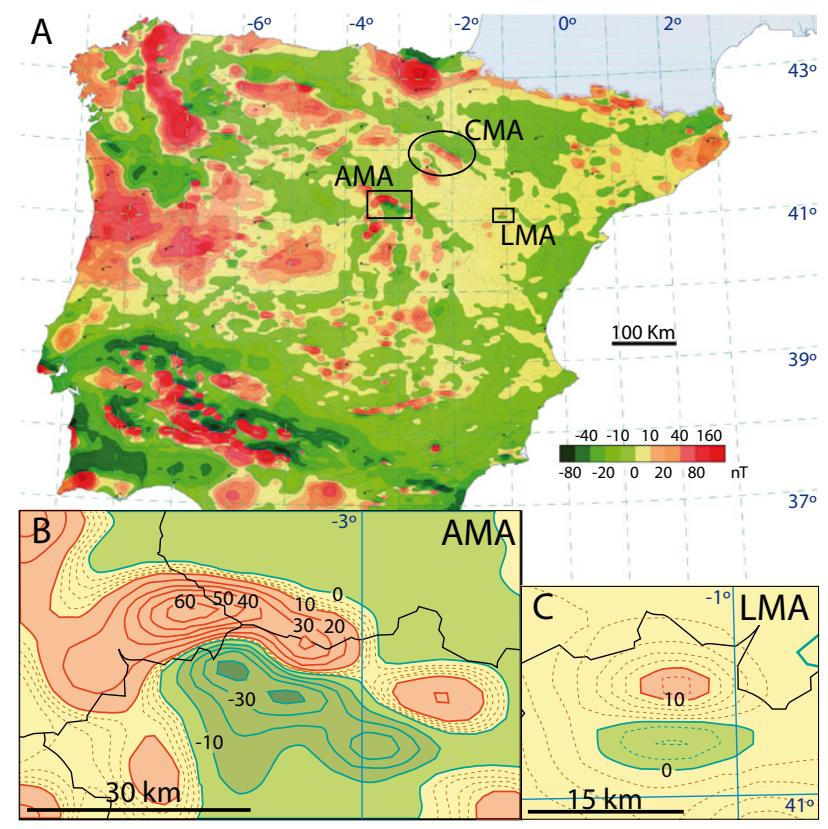

FIGURE 1. A) Magnetic map of the Iberian Peninsula (Socías and Mezcua, 2002) generated from aeromagnetic data measured in 1987 at an elevation of 3000m. CMA: Cameros Magnetic Anomaly, AMA: Atienza Magnetic Anomaly, LMA: Loscos Magnetic Anomaly. B) Atienza dipolar anomaly, that can be traced for $45 \mathrm{~km}$ along an E-W direction. C) Loscos dipolar anomaly. In C) and B): interval of dashed contours: $2 \mathrm{nT}$; interval of solid contours: $10 \mathrm{nT}$. the host rocks (Calvín-Ballester and Casas-Sainz, 2014), we propose the relation between these reverse dipolar anomalies and the magnetic remanence of Permian igneous rocks.

\section{STRUCTURAL AND STRATIGRAPHIC SETTING}

The reverse magnetic anomaly studied in this work is located in the northern sector of the Iberian Range, within the Variscan Herrera Unit (Fig. 2). This unit constitutes the NE limb of a kilometre-scale Variscan major anticline, with a predominant NW-SE to NNW-SSE trend and NE vergence. It is bounded to the SW by the Datos Faults (Carls, 1983), a first order structure, representing the boundary between different tectonostratigraphic domains: the Western Asturias-Leonese Zone and the Cantabrian Zone (Gozalo and Liñán, 1988; Calvín-Ballester and Casas-Sainz, 2014). The structure of this sector of the Herrera Unit is well constrained (Calvín-Ballester and Casas-Sainz, 2014), and it is characterized by E verging folds and folded thrusts, affected by Permian transtensional and extensional faults (Figs. 2C; 3; 4). Permian faults are related to igneous intrusions and resulted from the Late Carboniferous and Early Permian tectonics in the Iberian Peninsula, the latter resulting from dextral shear as a consequence of the relative movement between Gondwana and Laurasia (Arthaud and Matte, 1977). The Palaeozoic materials of the Iberian Range recorded a transtensive stress state, with the formation or reactivation of NW-SE major faults (i.e. Datos Fault) and associated half-grabens. Subsequently, these faults also controlled significant Mesozoic basins (Salas and Casas, 1993) and the Alpine compressional structure (De Vicente et al., 2009).

A more than $9000 \mathrm{~m}$ thick series characterizes the preVariscan stratigraphic succession of the Herrera Unit (Fig. 5). The Upper Cambrian-Silurian is formed by alternating, hectometre-thick sandstone and shale packages, topped by a shale unit approximately $1000 \mathrm{~m}$ thick. The Upper Silurian-Devonian shales, sandstones and bioclastic carbonates are the host rocks of the igneous intrusions.

The igneous rocks in this sector, as well as those cropping out in the Iberian Range as a whole, have been extensively studied by Lago et al. (2004, 2005) who distinguished: i) the Fombuena andesites (located a few kilometres northwards from the LMA), dated at $283 \pm 2.5 \mathrm{Ma}$ and $292 \pm 2.5 \mathrm{Ma}$ (K/Ar from biotites; Conte et al., 1987) and ii) the microgabbro dyke of Loscos which shows a radiometric age of $293 \pm 2.5 \mathrm{Ma}$ (K/Ar from biotite; Lago et al., 1991). According to these ages, igneous rocks were emplaced during the Kiaman reverse polarity superchron (Irving and Parry, 1963; Gradstein and Ogg, 2004). According to Lago et al. (2005), during the first magmatic stage (Late 


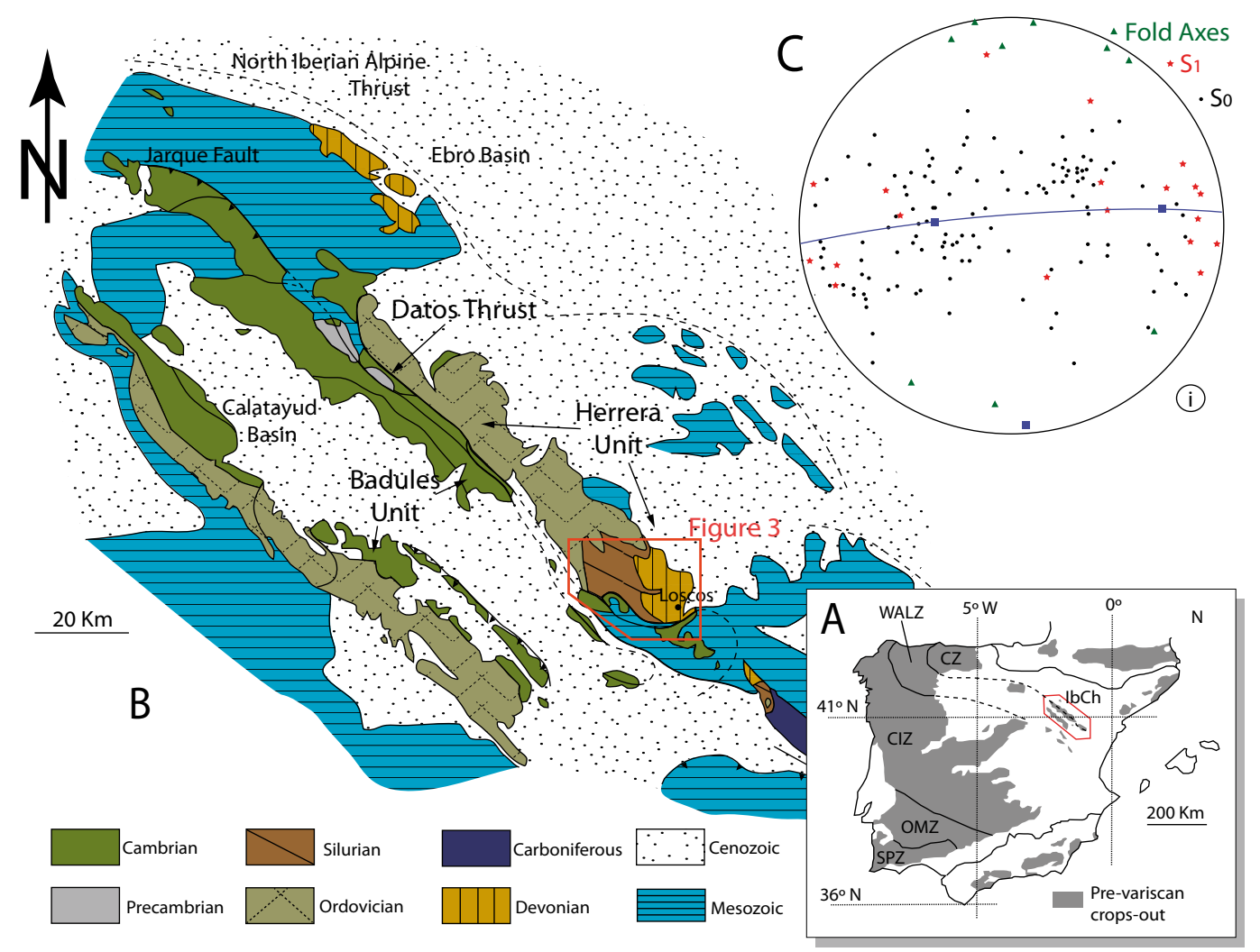

FIGURE 2. A) Location (in the outline) of the Iberian Chain (IbCh in the figure) in the Iberian Peninsula and main Palaeozoic tectonostratographic units: SPZ, South Portuguese Zone; OMZ, Ossa-Morena Zone; CIZ, Central Iberian Zone; WALZ, Western Asturias-Leonese Zone; CZ, Cantabrian Zone. B) Simplified geological map of the Aragonese Branch of the Iberian Chain. C) Stereoplot (Schmidt net; lower hemisphere) of bedding (SO) and structural indicators (cleavage, S1 and fold axes) indicators throughout the study area; they are consistent with a Variscan NNW-SSE regional folding. Modified after Gozalo and Liñán (1988) and Calvín-Ballester and Casas-Sainz (2014).
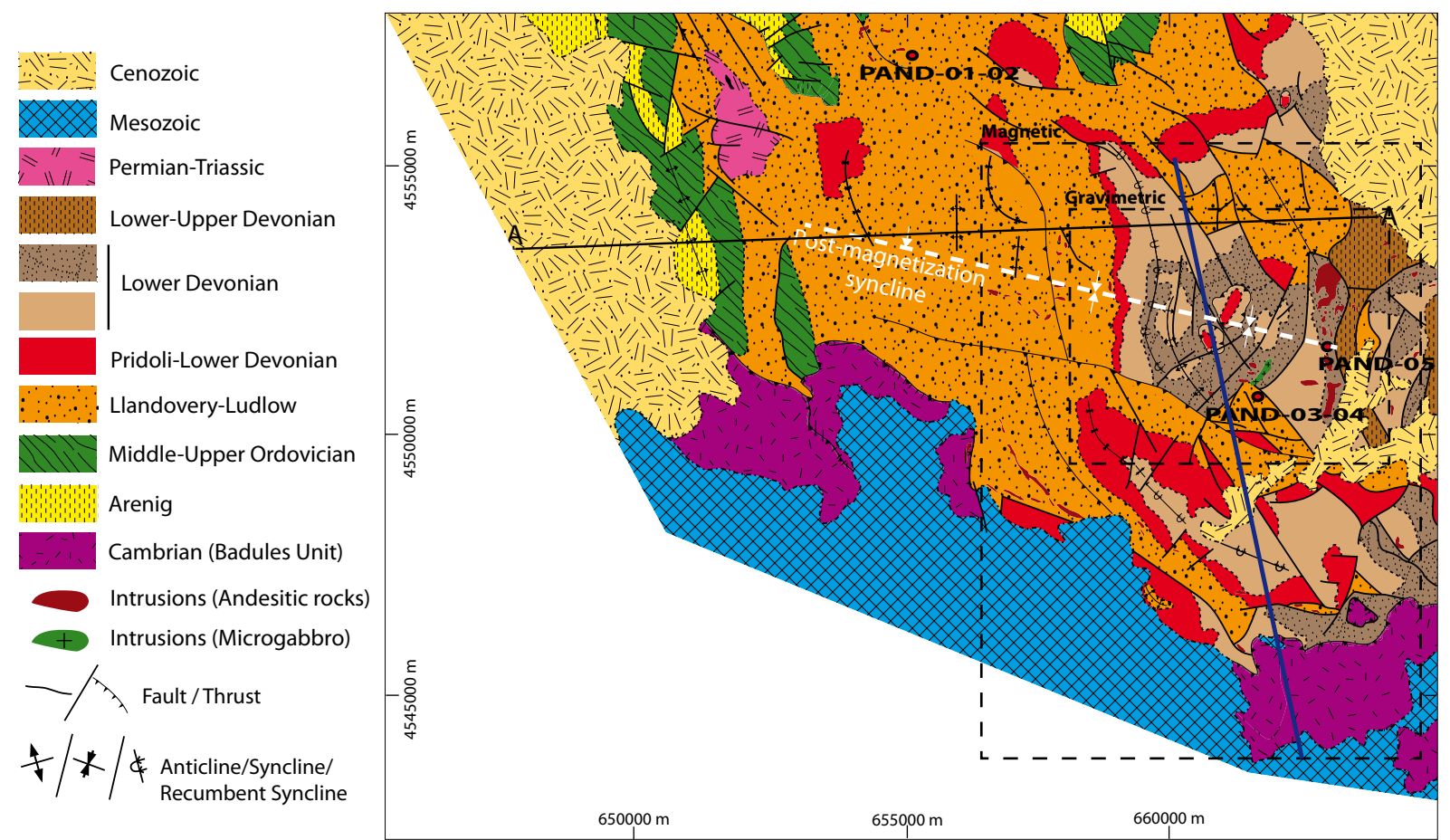

FIGURE 3. Detailed geological map of the studied area. Dashed-lined boxes show the location of magnetic and gravimetric maps (Figs. 6; 8). A-A' corresponds with geological cross section of Figure 4. NNW-SSE section corresponds to the profile selected for the interpretation. Projected coordinates, UTM30 ETRS89 (EPSG:6258). From Calvín-Ballester and Casas-Sainz (2014). 
w

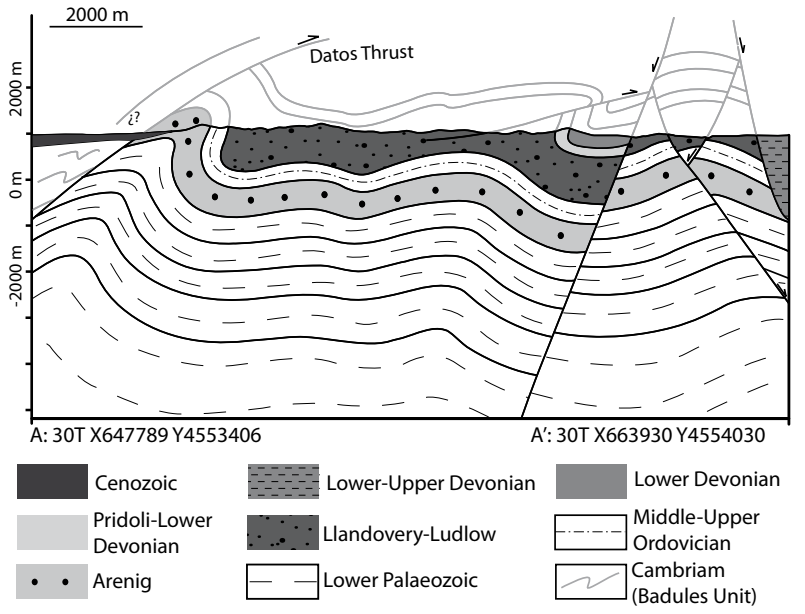

FIGURE 4. Geological cross-section of the study area (modified from Calvín-Ballester and Casas-Sainz, 2014). See location in Figure 3.

Stephanian-Early Permian), small half-grabens formed and were subsequently filled with volcanosedimentary, detrital and lacustrine deposits (e.g. Codos and Fombuena basins). This volcanic activity was fed by intermediateacid magmas, product of the interaction between mantlederived magmas and the crust. During the second stage (Early Permian), basic magmas directly derived from the mantle were emplaced as variable-sized intrusions. In the sector where the magnetic anomaly is found, small, strongly altered subvolcanic diorite bodies aligned with faults and a small outcrop of a microgabbro intrusion can be observed. Associated with the microgabbro, there are small polymetallic veins (López-Ciriano et al., 1997) distributed over an area wider than the outcrop of the microgabbro. This may indicate that the intrusive body is larger at depth than at surface. The Palaeozoic rocks are overlain by a thin cover (about 1500m) of Mesozoic rocks (mainly Triassic and Upper Cretaceous), gently folded during the Cenozoic compression (Cortés-Gracia and Casas-Sainz, 1996). To the NE of the studied area, a series of Cenozoic sediments more than $500 \mathrm{~m}$ thick defines the transition from the Iberian Chain to the Ebro Basin.

\section{METHODOLOGY}

New gravimetric and magnetic data were taken around the LMA to characterize the subsoil structure. The detailed geophysical survey consisted of 48 gravimetric sites (with 3 measurements per site) spaced about $1 \mathrm{~km}$, and 8 main magnetic profiles -six of them N-S and the rest E-W- with a total length of $40 \mathrm{~km}$ carried out in two field surveys (Fig. 6; Table 1)

To characterize the magnetic field, a rover magnetometer (GSM-19 GEM systems) based on the Overhauser effect,

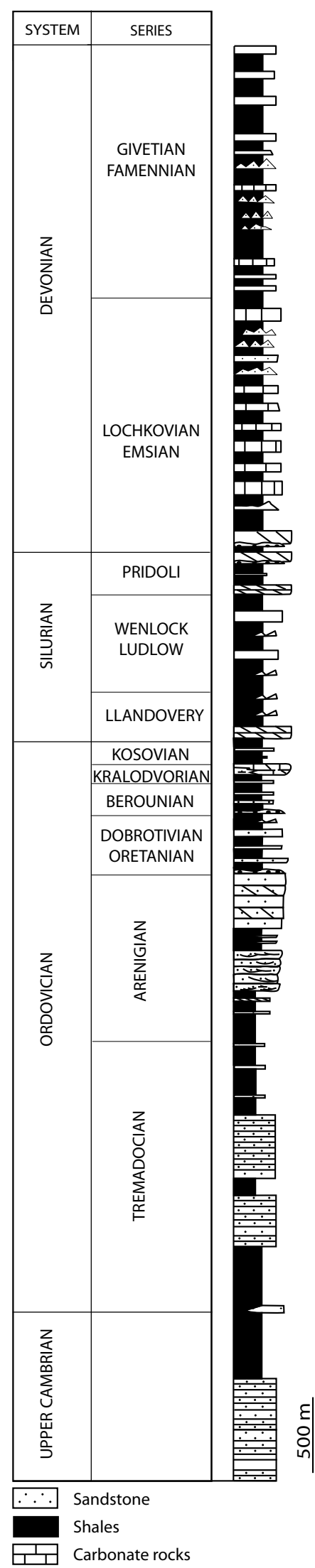

FIGURE 5. Synthetic stratigraphic section of the Palaeozoic materials of the Herrera unit. From Calvín-Ballester and Casas-Sainz, 2014. 

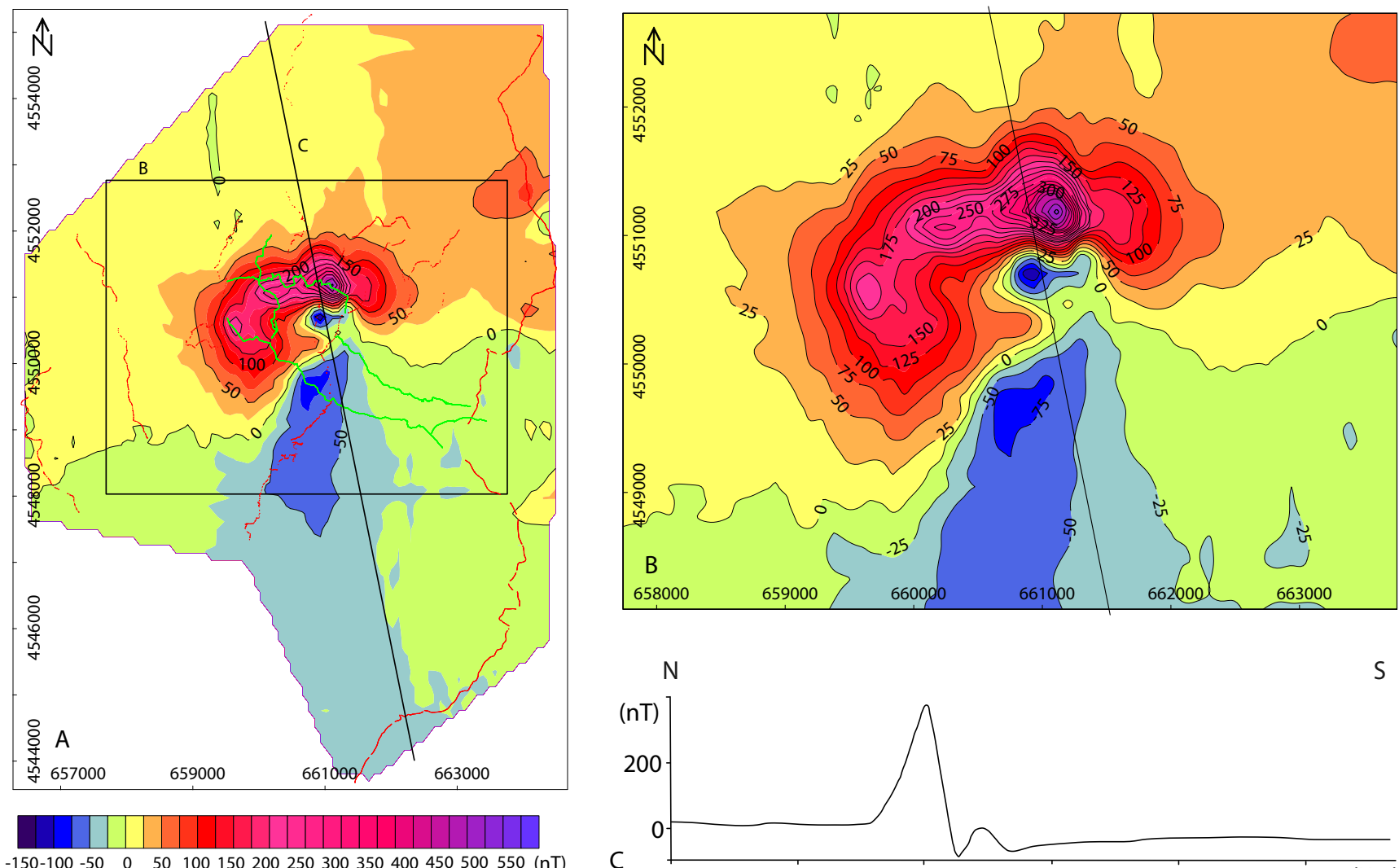

$\mathrm{N}$

$\mathrm{S}$

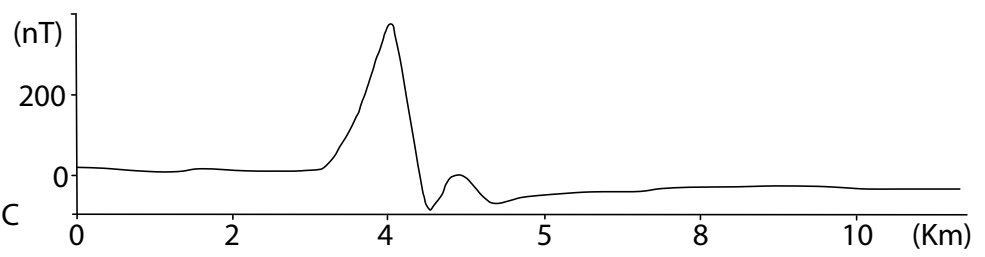

FIGURE 6. A) Total magnetic field anomaly map of the studied area; the points correspond to profiles of the magnetic survey and the white line represents the interpreted magnetic profile. Red triangles show the Field survey 1 and green diamonds show the Field survey 2 (Table 1). B) Detail of the central anomaly. C) Profile used in the interpretation of the anomaly. Projected coordinates, UTM30 ETRS89 (EPSG:6258).

TABLE 1 Petrophysical characteristic of the samples. k: susceptibility; $\mathrm{J}$ : natural remanence magnetization; Q: Koenigsberger index

\begin{tabular}{|c|c|c|c|c|}
\hline Site & Sample & $\begin{array}{c}\mathrm{k} \\
\left(\times 10^{-6} \text { S.I. }\right)\end{array}$ & $\begin{array}{c}\mathrm{J} \\
\left(\times 10^{-3} \mathrm{Am}^{-1}\right)\end{array}$ & Q \\
\hline \multirow[t]{4}{*}{ PAND-01 } & $1 \mathrm{~B}$ & 440 & 3.86 & 0.2195 \\
\hline & $2 A$ & 419 & 3.42 & 0.2041 \\
\hline & $3 B$ & 408 & 2.63 & 0.1613 \\
\hline & $4 \mathrm{~B}$ & 461 & 3.75 & 0.2031 \\
\hline \multirow[t]{3}{*}{ PAND-02 } & $1 \mathrm{~A}$ & 411 & 4.03 & 0.2453 \\
\hline & $2 B$ & 459 & 4.65 & 0.2533 \\
\hline & $3 B$ & 453 & 3.05 & 0.1683 \\
\hline \multirow[t]{3}{*}{ PAND-03 } & 1B & 391 & 20.46 & 1.3070 \\
\hline & $2 B$ & 431 & 22.56 & 1.3078 \\
\hline & $3 B$ & 276 & 11.28 & 1.0231 \\
\hline \multirow[t]{3}{*}{ PAND-04 } & 1B & 348 & 2.23 & 0.1602 \\
\hline & $2 B$ & 356 & 2.57 & 0.1803 \\
\hline & $3 B$ & 339 & 1.71 & 0.1307 \\
\hline \multirow[t]{6}{*}{ PAND-05 } & $1 \mathrm{~B}$ & 179 & 0.27 & 0.0377 \\
\hline & $2 B$ & 181 & 0.31 & 0.0426 \\
\hline & $3 B$ & 181 & 0.36 & 0.0490 \\
\hline & 4B & 189 & 0.23 & 0.0374 \\
\hline & $5 B$ & 183 & 0.30 & 0.0411 \\
\hline & $6 B$ & 176 & 0.37 & 0.0521 \\
\hline
\end{tabular}

with a precision of $0.1 \mathrm{nT}$, was used. A proton magnetometer (PGM-01 Czech Republic) was used as a base to account for diurnal corrections. Data were filtered to eliminate local anomalies related to human activity, and subsequently the diurnal variations (using the lecture of the magnetometer base) and the International Geomagnetic Reference Field (IGRF) were removed.

The gravity field was recorded with a Burris ZLS gravimeter, with an accuracy of $0.01 \mathrm{mGal}$ and instrumentrelated drift of less than $0.01 \mathrm{mGal}$ during the survey period. Gravity readings were referred to the IGSN-71 through the absolute gravity base located at the University of Zaragoza. A comparison between observed gravity values and theoretical model based on the Geodetic Reference System (GRS80; Moritz, 1980) was carried out. Free Air Correction (Hinze et al., 2005) and Bouguer correction considering an average density of the materials of $2670 \mathrm{kgm}^{-3}$ (LaFehr, 1991) were also applied. Topographic correction was applied up to $20 \mathrm{~km}$, with a Digital Terrain Model using a 100x100m topographic grid, based on the Hammer chart (Hammer, 1939). Bouguer anomaly map was generated through interpolation (kriging) of data. The residual anomaly map was generated by subtracting 
the regional anomaly (obtained manually by smoothing the Bouguer anomaly map according with the regional geology) from the Bouguer anomaly.

From five different outcrops of igneous rocks (see location in Fig. 3), oriented hand-samples were collected and drilled in the lab as standard magnetic cores to analyse their density and magnetic properties: susceptibility (with a KLY-3 Kappabridge from Agico), Natural Remanent Magnetization (NRM, Superconducting magnetometer 2G 755), density (precision balance using the weight of the sample in air and water) and susceptibility thermomagnetic curves (CS-03 coupled to KLY-03 Kappabridge from Agico). The susceptibility of the host rock was measured through multiple measurements with a handheld KT-10 susceptometer (Terraplus-Canada). In addition, alternating field demagnetisation was applied to representative samples by means a $2 \mathrm{G}$ cryogenic magnetometer, and thermomagnetic curves of induced magnetisation were obtained by a Variable Field Translation Balance (MMVFTB). All measurements were done at the Paleomagnetic Laboratory of the Burgos University and the Magnetic Fabrics Laboratory of the Zaragoza University.

In the processing of results, interpolation of the data was performed by kriging, generating a 70x70m grid. This interpolation method was found to give the best results, because of the uneven distribution of magnetic data. Upward continuation was done throughout the software MagPick (Geometrics) using Tikhonov regularization. 2.5D modelling of the terrestrial magnetic anomaly and of the Upward continuation was carried out with Gravmag software (British Geological Survey). 2.5D modelling allowed to estimate the source of the anomalies. However, this method shows some limitations: it assumes that modelled bodies are symmetric in regard to the modelled cross-section, biasing the model when there are heterogeneities, oblique or perpendicular to the considered cross-section. In order to assess the rock types and their possible alteration, thin sections from selected samples were studied under petrographic microscope.

\section{RESULTS}

\section{Magnetic anomaly}

The total magnetic field anomaly map (Fig. 6A) shows a complex pattern. On one hand, it shows a wide smallintensity anomaly covering the whole studied area. On the other hand, it overlaps with another anomaly with smaller wavelength and higher intensity (Fig. 6B), elongated in $\mathrm{E}-\mathrm{W}$ direction. This wavelength is about $2.5 \mathrm{~km}$ in $\mathrm{N}-\mathrm{S}$, and $3.5 \mathrm{~km}$ in $\mathrm{E}-\mathrm{W}$ direction, with a positive amplitude in
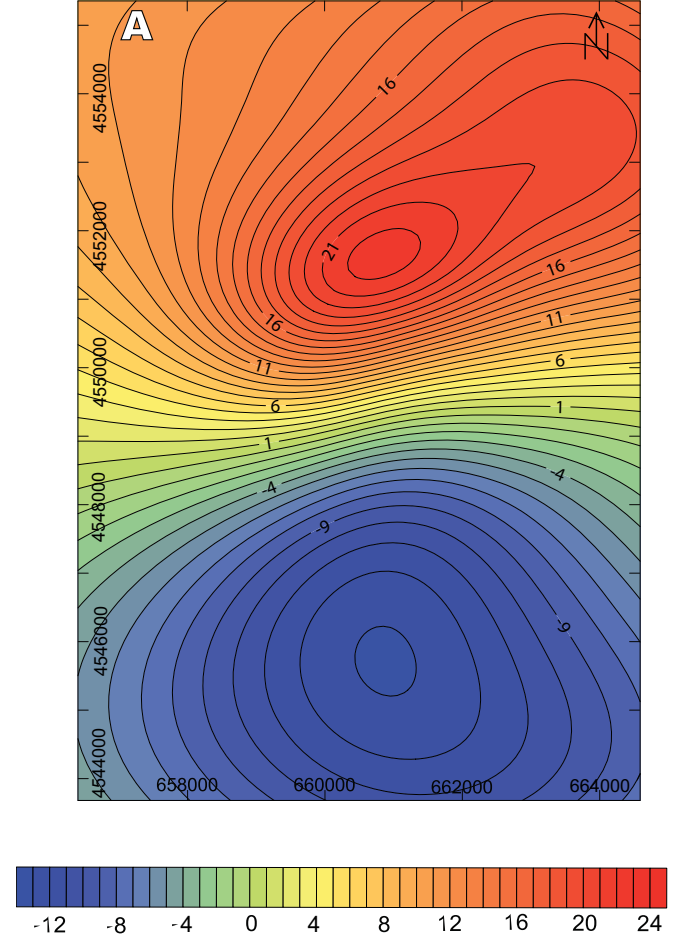

(nT)

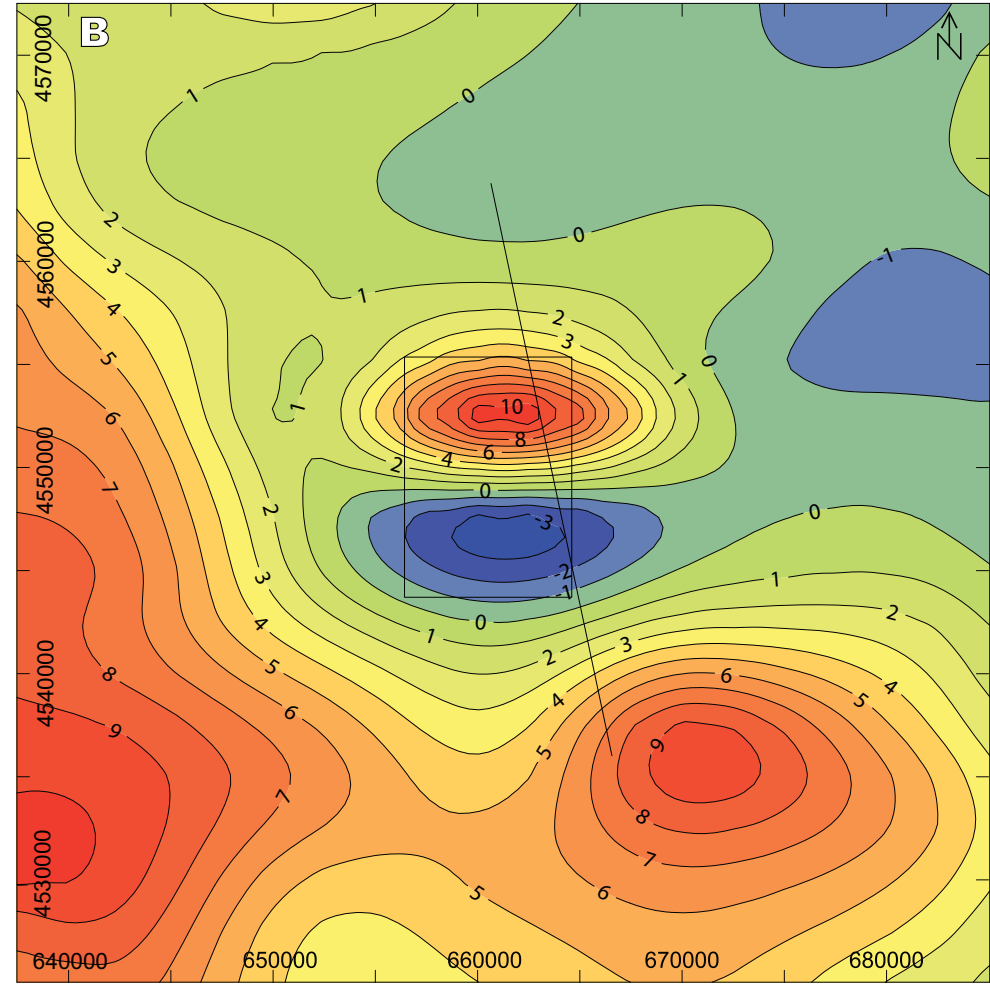

FIGURE 7. A) Upward continuation for $2000 \mathrm{~m}$ above the surface with an average surface height of 1000m. B) Detail of the Magnetic map of the Iberian Peninsula (Ardizone et al., 1989) over the Loscos Magnetic Anomaly, generated from aeromagnetic data measured in 1987 at an elevation of $3000 \mathrm{~m}$. Projected coordinates, UTM30 ETRS89 (EPSG:6258). 
the $\mathrm{N}$ of around 300nT and a negative amplitude in the $\mathrm{S}$ of $-100 \mathrm{nT}$ (Fig. 6B); the central sector of the anomaly is very complex and a single dipole cannot be clearly defined (Fig. 6C), due to the contribution of several anomalies with variable intensities and wavelengths.

An Upward continuation map for $2000 \mathrm{~m}$ above the surface (considering a mean surface height of $1000 \mathrm{~m}$ ) was calculated (Fig. 7A). This map shows a reverse magnetic dipole very similar to the one observed in aeromagnetic map (Fig. 1; 7B) with a wavelength longer than the survey area, a maximum intensity of $20 \mathrm{nT}$ in the northern sector, and a minimum of about $-15 \mathrm{nT}$ in the southern sector.

\section{Gravimetric anomaly}

The Bouguer anomaly (Fig. 8A) shows a gradient with less negative values to the ENE, nearly perpendicular to the limit between the Iberian Range and the Tertiary Ebro Basin. This limit controls the NNE-SSW disposition of
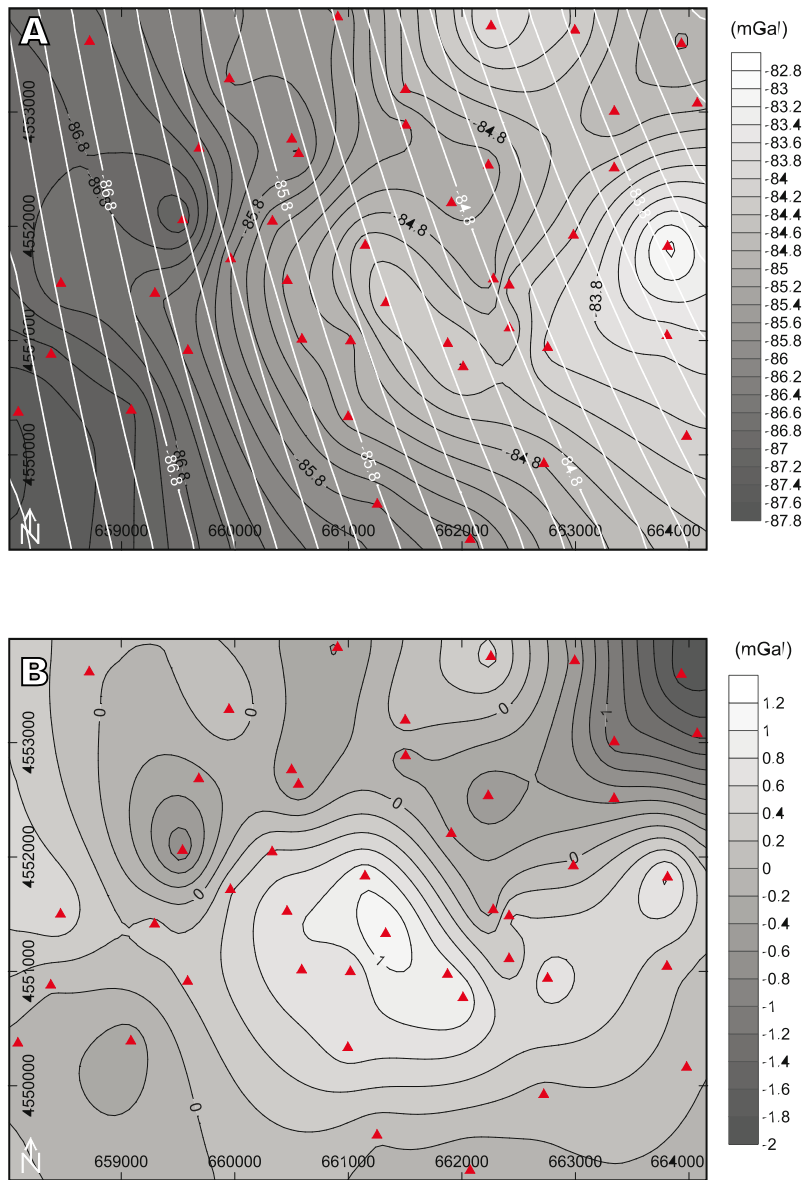

FIGURE 8. A) Bouguer anomaly map (black lines and grey-scale background) and regional gravimetric map (white, dashed lines). B) Residual gravimetric anomaly map obtained by the subtraction of the regional gravimetric to Bouguer anomaly map. The points represent the gravimetric measurements sites. Projected coordinates, UTM30 ETRS89 (EPSG:6258).(EPSG:6258). the regional field (Fig. 8A), that shows increasing values toward the ENE, related to crustal thinning in this direction (Salas and Casas, 1993). In the central sector, where igneous rocks crop out, the values of the Bouguer anomaly are higher. The residual anomaly map (Fig. 8B) shows a small positive anomaly $(3.5 \times 2 \mathrm{~km})$ in the centre of the study area (maximum $1.4 \mathrm{mGal}$ ) elongated in NW-SE direction. In the NE edge of the survey area, a negative anomaly can be observed, but this may be due to border effect in the interpolation at the boundary of the study area.

\section{Physical properties}

In general, the studied igneous rocks show low to moderate values of susceptibility $(\mathrm{k})$ and remanence (J) (Table 1). J-k plot (Fig. 9) indicates four populations controlled by petrofacies. PAND-01 and PAND-02 represent subvolcanic rocks with low remanence and high relative susceptibility $\left(\mathrm{k}=350-450 \times 10^{-6}\right.$ S.I. $)$. PAND-03 and PAND-04 correspond to a microgabbro dyke; PAND03 shows higher ratios of remanence to susceptibility $\left(\mathrm{J}>0.01 \mathrm{Am}^{-1}\right)$, while PAND-04 shows the opposite relationship, indicating a significant heterogeneity in the initial ferromagnetic composition of the dike or a subsequent alteration. Finally, PAND-05 corresponds with a felsic dyke and shows low values of susceptibility and remanence. The host rock shows susceptibility values around $200-300 \times 10^{-6}$ S.I. in shales and limestones and $0-30 \times 10^{-6}$ S.I. in quartzitic sandstones.

NRM directions of the samples (Table 2; Fig. 10A) show Permian declinations $\left(\mathrm{D}=163.0^{\circ} ; \mathrm{I}=-8.9^{\circ}\right.$, according to Osete et al., 1997) in PAND-01 to PAND-04 ( $\mathrm{D}$ between $170^{\circ}$ to $180^{\circ}$ ), but with an important scattering in inclination (I between $22.7^{\circ}$ and $-35.3^{\circ}$ ). This dispersion is related to the location of the samples because PAND-01 and PAND-02 (both with positive inclination) are located about 9km to the NW of PAND-03 and PAND-04 (both with negative inclination).

Some representative samples were demagnetized by alternating fields in order to determine the component structure of the NRM. Most samples showed an only stable low coercivity component (Fig. 10C) with coercivity spectra comprised between 10 and $80 \mathrm{mT}$. This univectorial feature indicates that the NRM directions (Table 3; Fig. 10A) are reasonably representative of the isolated paleomagnetic component.

Thermomagnetic magnetization curves have been performed in representative samples. The hyperbolic heating curves in PAND-02 and PAND-03 indicate that most of the magnetic signal is dominated by the paramagnetic fraction (Fig. 11A, C). An increase of the magnetization is observed in the cooling path, owing to 
TABLE 2. Values of declination (D), inclination (I) and Fisher statistical parameters ( $k$ and $\alpha 95$ )

\begin{tabular}{lrrrrrrrrr}
\hline & \multicolumn{4}{c}{ In situ coordinates } & \multicolumn{4}{c}{ After tectonic correction } \\
Sample & $\mathrm{n}$ & $\mathrm{D}\left({ }^{\circ}\right)$ & $\mathrm{I}\left({ }^{\circ}\right)$ & $\mathrm{k}$ & $\alpha_{95}$ & $\mathrm{D}\left({ }^{\circ}\right)$ & $\mathrm{I}\left({ }^{\circ}\right)$ & $\mathrm{k}$ & $\alpha_{95}$ \\
\hline PAND-01 & 7 & 177.1 & 10.5 & 53.6 & 8.3 & 177.0 & -14.5 & 53.8 & 8.3 \\
PAND-02 & 6 & 180.2 & 23.6 & 64.4 & 8.4 & 180.2 & -01.4 & 64.3 & 8.4 \\
PAND-03 & 6 & 170.0 & -28.4 & 51.8 & 9.4 & 171.2 & -03.7 & 52.0 & 9.4 \\
PAND-04 & 4 & 179.8 & -35.9 & 133.5 & 8.0 & 179.8 & -10.9 & 132.6 & 8.0 \\
Site means & 4 & 176.8 & -7.6 & 7.7 & 35.3 & 177 & -7.6 & 12.8 & 8.4 \\
\hline
\end{tabular}

the generation of ferromagnetic minerals during heating, probably from paramagnetic minerals. This non-reversible shape of the curves suggests that the grains that transform in new ferromagnetic minerals during the experiments must be created after the original cooling during formation (Carrancho and Villalaín, 2011). This observation also indicates that chemical alteration affected these rocks to some degree after original cooling during formation. After subtracting the paramagnetic contribution (Fig. 11B, D), the Curie temperature of $585^{\circ} \mathrm{C}$ can be interpreted as due to the presence of magnetite in PAND-03 (Fig. 11C). In PAND-02 a drop at $450^{\circ} \mathrm{C}$ can be observed and after this temperature the creation of new ferromagnetic minerals can be observed (Fig. 11D).

The density contrast between the igneous and host rocks is around $120 \mathrm{kgm}^{-3}$ (Fig. 12). Multiple density measurements of igneous rocks show a mode of $2750-2800 \mathrm{kgm}^{-3}$ with strong variability, and some values below the average of the host rocks (considering the different lithologies: shales, sandstones and limestones). Conversely, the host rocks have values distributed between 2550 and $2775 \mathrm{kgm}^{-3}$.

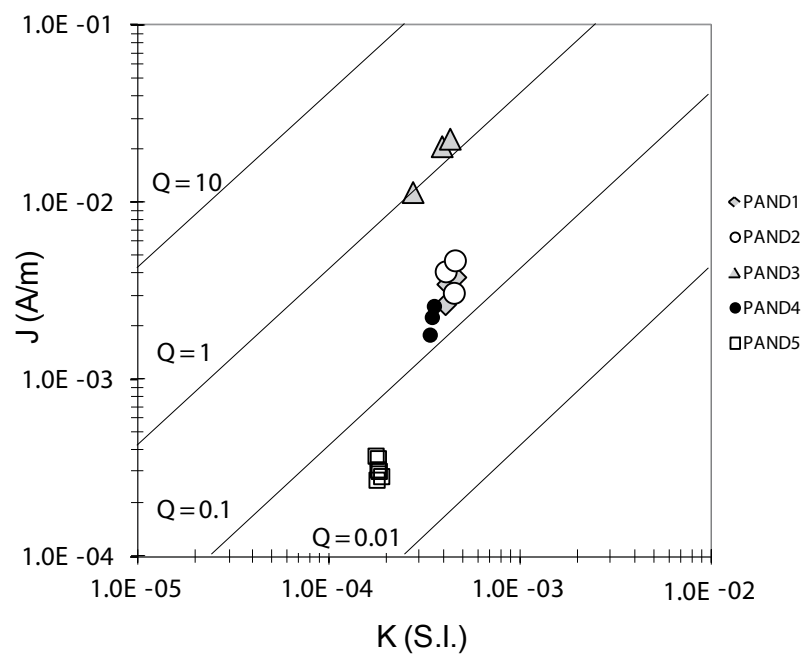

FIGURE 9. J-k (remanence-susceptibility) graphic showing the analysed samples. Koenigsberger ratios $Q(Q=N R M /(k H)$, where $k$ is the magnetic susceptibility and $\mathrm{H}$ is the ambient fiel $\sim 40 \mathrm{~A} / \mathrm{m}$ ) are also shown.

\section{Petrography of rock alteration}

\section{Gabbros (PAND-03, PAND-04)}

Gabbros show phaneritic, slightly porphyritic texture (Fig. 13A, B) formed by Pl (65\%), Cpx $(20 \%$ -partially altered to Amp: 5\%-), Bt (10\%), Opq (5\%) and intercrystalline Qz (1\%) (mineral abbreviations in this work follow recommendations by Whitney and Evans, 2010). Alteration minerals as Chl or phyllosilicates are also present.

In most cases, Cpx macrocrysts have undergone hydration processes, which isomorphically changed the primary Cpx to secondary Amp. This kind of processes, as well as other alterations, are better recognized in PAN-D04 than in PAN-D03, which is much less altered.

\section{Diorite dikes (PAND-01, PAND-02)}

They are subvolcanic, holocrystalline rocks (Fig. 13C), mainly characterized by intergranular textured matrix with some coarser crystals as $\mathrm{Pl}$ phenocrysts and Qz xenocrysts. The mineral assemblage of these rocks is: $\mathrm{Pl}(65 \%), \mathrm{Bt}$ (10-15\%), secondary Chl (5-10\%), Opq (5-10\%) and xenocrystalline Qz (5\%). The matrix is basically formed by $\mathrm{Pl}, \mathrm{Bt}$ and Opq. Some vesicles filled by $\mathrm{Chl} \pm \mathrm{Qz}$ have also been observed.

The alteration degree of the two studied samples is clearly different. While PAN-D01 remains less altered, PAN-D02 shows a higher alteration degree, especially recognized in the $\mathrm{Pl}$ crystals (altered to phyllosilicates - e.g. sericite-) and in a greater modal proportion of secondary Chl.

\section{Rhyolite dykes (PAND-05)}

Volcanic, strongly porphyritic holocrystalline rocks, with a fine-grained matrix mainly formed by $\mathrm{Qz}(+\mathrm{Bt}$ $\pm \mathrm{Pl}$ ) and almost totally altered $\mathrm{Ab}$ and $\mathrm{Bt}$ phenocrysts. The rock shows a strong alteration degree and modal mineral proportions are difficult to define. The matrix 
TABLE 3. Magnetic properties of the modelled bodies and host rock used in the interpretation of the synthetic model (Fig. 14B)

\begin{tabular}{lrrrrrrr}
\hline $\begin{array}{l}\text { Polygon } \\
\text { number }\end{array}$ & $\begin{array}{c}\Delta \rho \\
\left(\mathrm{kgm}^{-3}\right)\end{array}$ & $\begin{array}{c}\Delta \mathrm{k} \\
\left(\times 10^{-6} \mathrm{~S} . \mathrm{I} .\right)\end{array}$ & $\begin{array}{c}\Delta \mathrm{J} \\
\left(\times 10^{-3} \mathrm{Am}^{-1}\right)\end{array}$ & Q-value & $\begin{array}{r}\text { Remanent } \\
\text { declination }\end{array}$ & $\begin{array}{r}\text { Remanent } \\
\text { inclination }\end{array}$ & $\begin{array}{r}\text { Half Strike } \\
(\mathrm{m})\end{array}$ \\
\hline 01 & 63 & 14670 & 44.0 & 0.07 & 177 & -32 & 500 \\
02 & 23 & 1360 & 626.7 & 11.52 & 177 & -32 & 700 \\
03 & 25 & 22050 & 889.4 & 1.01 & 177 & -32 & 600 \\
04 & 06 & 25290 & 1020.2 & 1.01 & 177 & -32 & 500 \\
05 & -117 & - & - & - & - & - & 300 \\
\hline
\end{tabular}

is integrated by: Qz (80\%), Bt (15\%), Pl (5\%) and Opq $(1-3 \%)$. Bt crystals are totally anhedral and show alteration colours (yellow, red, orange) probably due to the presence of transition metals oxides. The Pl crystals are also anhedral and display rounded to circular habits. The strong physical and chemical alteration erased most of their crystal features.

\section{INTERPRETATION AND DISCUSSION}

\section{Representativeness of samples}

Before performing the modelling of magnetic and gravimetric anomalies, it is convenient to analyse the representativeness of the studied samples to understand
E Up

90

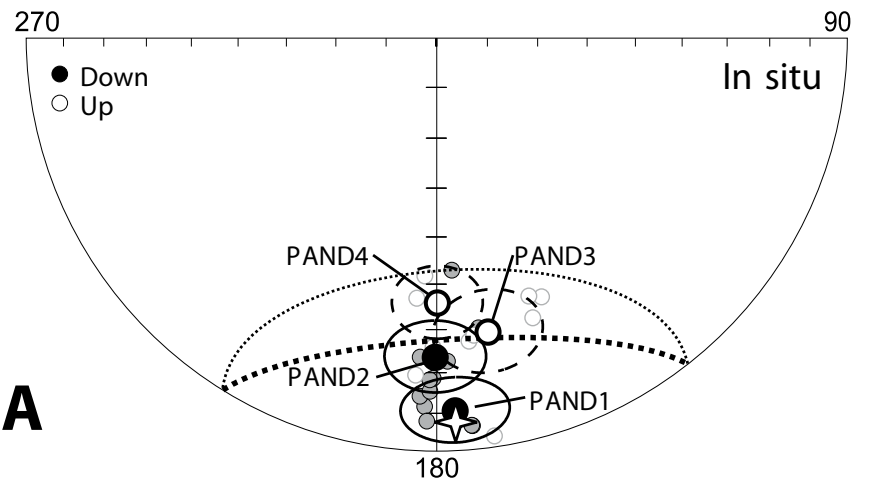

270

90

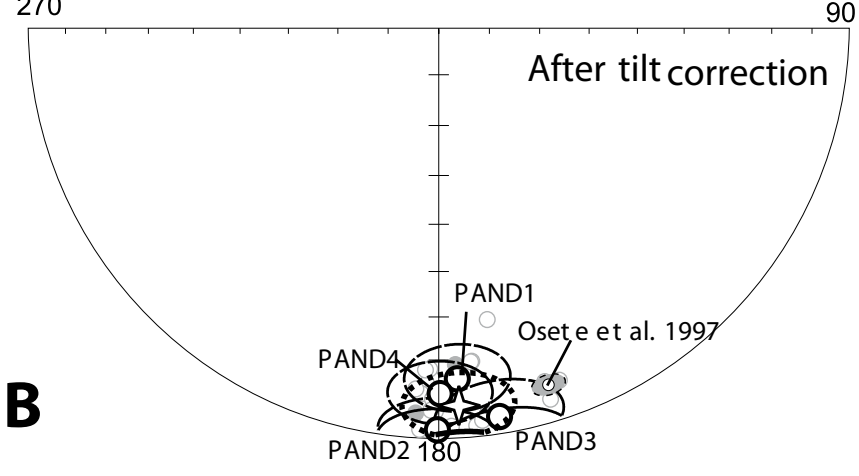

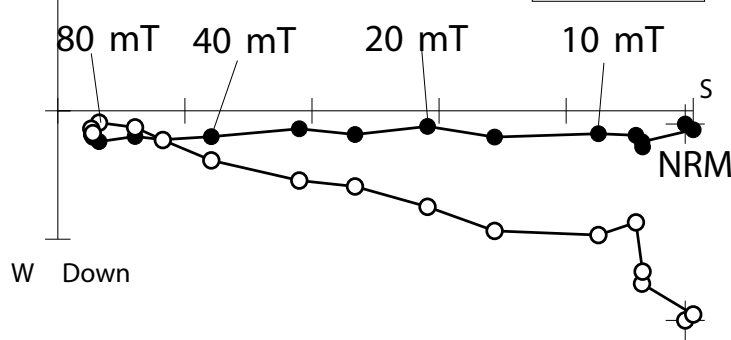

E Up

PAND3-2B

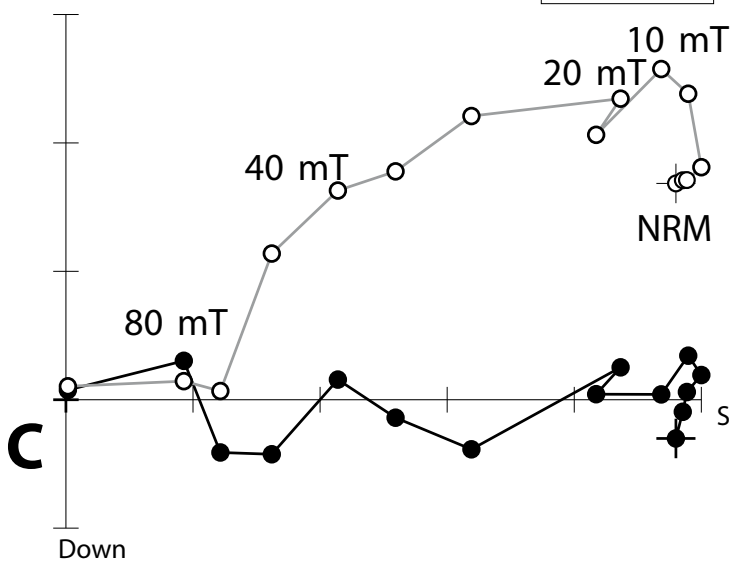

FIGURE 10. A) Equal area projections showing in situ NRM direction of samples (grey) and mean site directions with corresponding 95\% confidence circle (black) of four sampling sites in andesites and gabbros. Solid symbols are plotted on lower hemisphere and open symbols on upper hemisphere. Mean of site mean direction is also indicated (star) and the corresponding 95\% confidence circles (dotted lines) are also indicated. B) Same information as A), restored to the horizontal assuming that PAND-1 and PAND-2 are located in the northern limb (tilted $25^{\circ}$ ) of a E-W syncline tilted, while PAND-3 and PAND-4 are located at the southern limb (also tilted 25\%). Mean paleomagnetic direction and 95 obtained by Osete et al. (1997) in Atienza andesites are also represented. C) Orthogonal projections in in situ coordinates of alternating field demagnetization of two representative samples of andesite (up) and gabbro (down). Open symbols are projections of the vector end points onto the vertical N-S plane and solid symbols are projections onto the horizontal plane. 

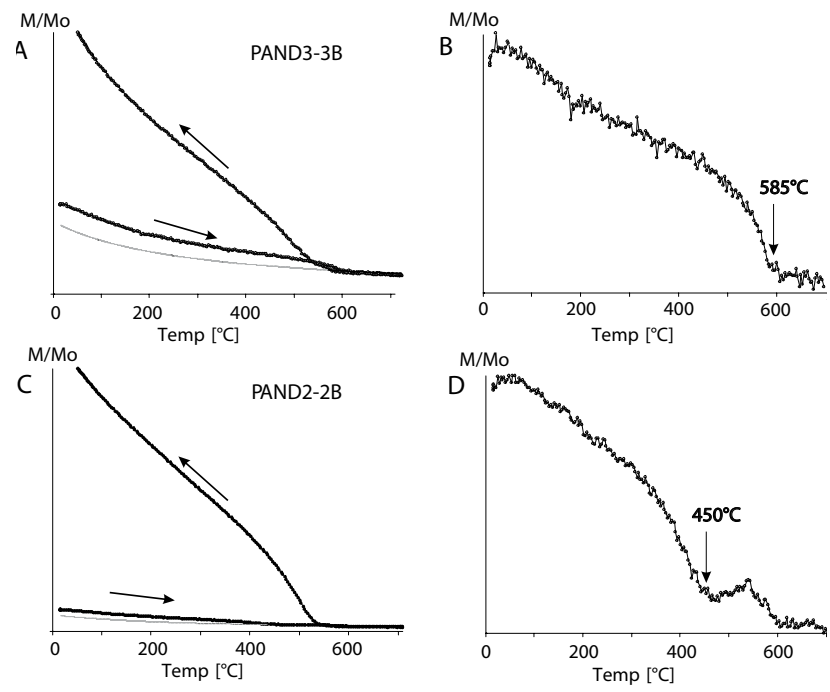

FIGURE 11. Thermomagnetic curves for PAND-02 ( $A$ and $B$ ) and PAND03 ( $C$ and $D) . A$ ) and $C$ ) show heating and cooling cycles (indicated by arrows) without any correction. Grey line indicates the contribution of paramagnetic fraction. B) and D) show the heating cycles after subtracting the paramagnetic contribution.

the nature of the body which generates the magnetic anomaly.

NRM directions show approximately Permian directions (Osete et al., 1997), but affected by E-W post magnetization folding, generating dispersion in the inclination in a N-S section (Fig. 10A), compatible with

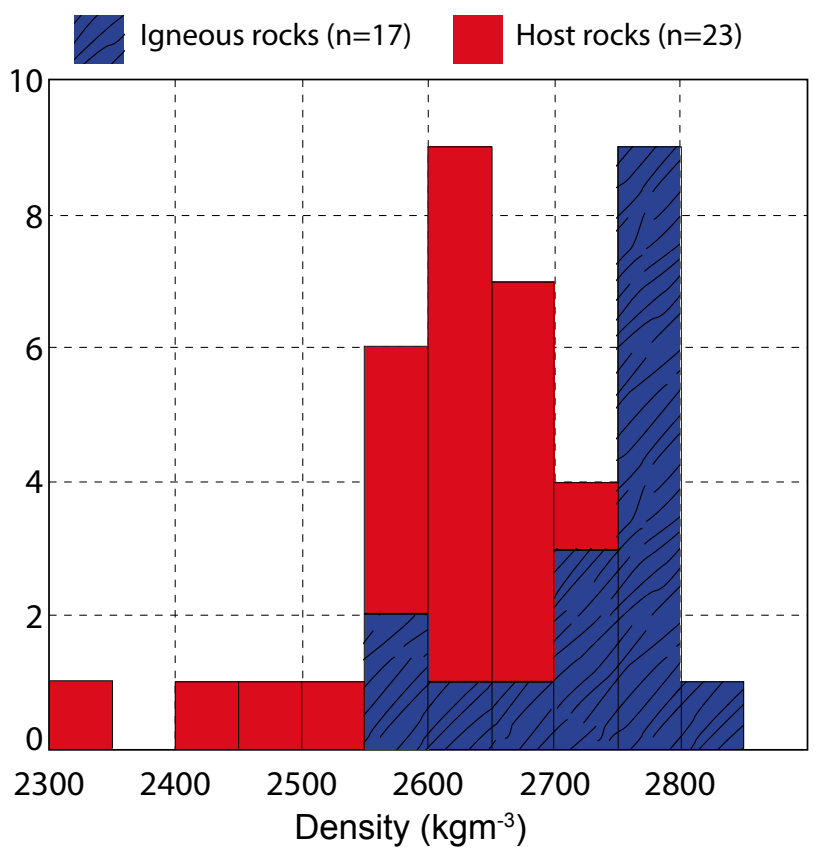

FIGURE 12. Frequency histogram of densities of the igneous and host rocks in the study area.
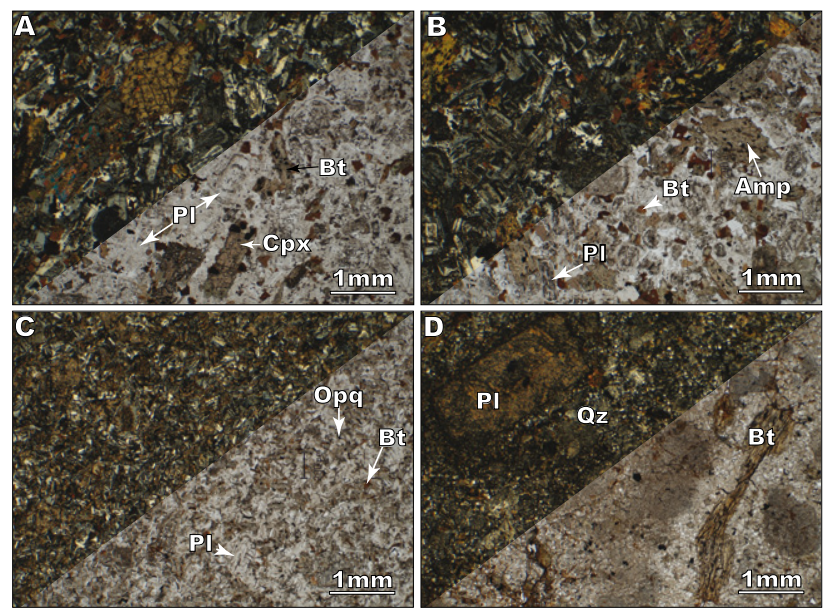

FIGURE 13. Microscopic images of the three different groups of rocks in the study area. Each image is divided into two sectors: left-side sectors correspond to crossed nicols images and right-side sectors correspond to parallel nicols images. A) Phaneritic texture in gabbro. In this sample the alteration is moderate and some Cpx phenocrysts remain nearly non-altered (PAND-03). B) Phaneritic texture in gabbro. In this case, the alteration is higher, Cpx phenocrysts are altered to Amp and mica and sometimes the former appear as pseudomorphs composed of Amp microcrysts (PAND-04 sample). C) Intergranular general texture in andesite. The alteration degree is not high (PAND-02 sample). D) Strongly porphyritic texture in rhyolite. Note the extensive alteration. The PI phenocrysts are fully altered and Bt phenocrysts are altered and fractured (PAND-05 sample).

compressional E-W structures (typical Alpine trend in this sector; Cortés-Gracia and Casas-Sainz, 1996). Besides, this is compatible with the WNW-ESE thrust located towards the S, which cuts across NNW-SSE Variscan structures. Furthermore, the axis of the NNW-SSE syncline located between PAND-01 and -02 on one side and PAND-03 and 04 on the other shows a southward dip of about $30^{\circ}$ resulting from tilting of the structure (according to the attitude of unconformable Mesozoic beds located South of it). Therefore, if we assume that NRM directions are rotated $25^{\circ}$ to the $\mathrm{N}$ (PAND-01, PAND-02) and $25^{\circ}$ to the $\mathrm{S}$ (PAND-03, PAND-04 respectively), according to their location, with an E-W horizontal axis, resulting NRM directions show a significant clustering after tectonic correction (Fig. 10B), indicating the presence of an E-W syncline formed after magnetization, probably during Cenozoic times.

On the other hand, low $\mathbf{J}$ and $\mathrm{k}$ values indicate an important alteration of ferromagnetic phases in the analysed igneous rocks. Urrutia-Fucugauchi et al. (2012) indicate that primary direction and intensity of remanence in igneous rocks can be modified by different processes related to igneous activity (e.g. hydrothermal alteration or reheating). However, according to NRM directions and orthogonal projections of alternating field demagnetization (Fig. 10), no evidence of formation of new ferromagnetic minerals during the alteration process has been found and 
only anomalously low values of magnetisation intensity are recognized, but without generating a remagnetisation.

The petrographic analysis shows important differences in alteration in different bodies, which may indicate significant heterogeneities throughout the plutonic rocks. In addition, as mentioned above, the wide area with outcrops of polymetallic veins associated with gabbroic rocks (López-Ciriano et al., 1997) may be a clear indicative of the further extension of these rocks in depth.

For all these reasons, the presence of heterogeneous igneous bodies in the subsurface with Permian NRM and values of remanence higher than those measured in outcrops, can be a working hypothesis to interpret the potential field anomalies obtained. This is illustrated in Figure 14, which shows the impossibility to reproduce the observed anomaly with the properties of rocks analysed at surface.

\section{Qualitative model}

An approach to deciphering the origin of potential field anomalies is the construction of conceptual models not exactly reproducing all the details of the obtained anomaly but defining its overall geometry. In our case, 2.5D quantitative modelling is not possible because: i) the petrophysical properties of the true source are not known and ii) the anomaly is complex, with several lateral inhomogeneities, denoting differences in lateral continuity of the source bodies $(2.5 \mathrm{D}$ modelling assumes a symmetrical extension to the bodies relative to the modelled section). Furthermore, a combined gravitymagnetic modelling is precluded by the fact that the gravimetric anomaly is small $(1.4 \mathrm{mGal})$, close to the limit and resolution of the survey and is slightly shifted toward the $\mathrm{E}$ with respect to the magnetic anomaly (recall here that because of the very nature of the $2.5 \mathrm{D}$ modelling, the modelled seccion should cross at the axis of symmetry of the gravimetric anomaly).

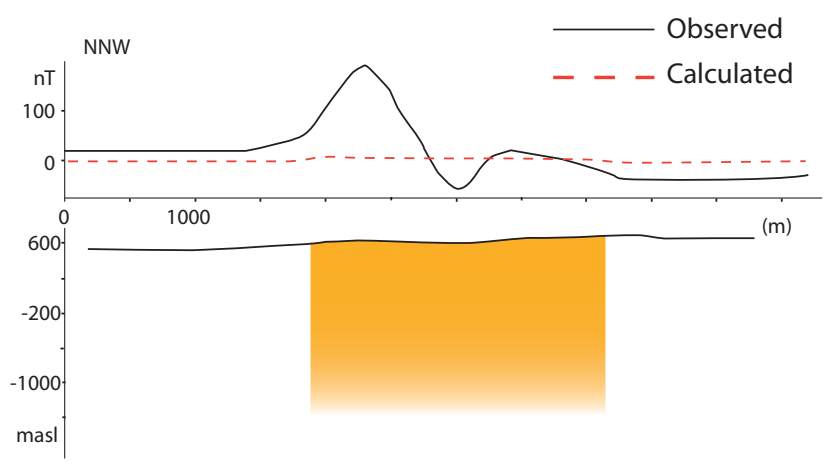

FIGURE 14. F2.5 modelling using the measured magnetic properties of the analysed igneous rocks.
From petrophysics and paleomagnetic data, the reverse magnetic anomaly can be interpreted to be generated by an igneous body with a high remanence value and reverse polarity. The outcropping gabbroic body may be a part of this body, but it is affected by a slight alteration generated on the surface. This igneous body might also be the cause for the gravimetric anomaly. An attempt can be made from a qualitative approach, in order to infer the petrophysical characteristics that a hypothetical causative body could have, to generate the complex reverse magnetic anomaly. The basic concept of this qualitative model can also be extrapolated to other reverse magnetic anomalies related to Permian igneous rocks.

The analysis of the magnetic map (Fig. 6), the upward continuation to $3000 \mathrm{~m}$ elevation (Fig. 7B) and the aeromagnetic map (Figs. 1; 7A) give valuable information about the disposition of the source bodies, which has been used to perform the modelling. The magnetic map (Fig. 6) shows an anomaly with a long wavelength but low intensity, which is the cause for the positive values (20nT) in the northern sector and negative $(-35 \mathrm{nT})$ in the southern sector. This feature, which is also recognizable in the maps to an elevation of $3000 \mathrm{~m}$ (Figs. 1; 7), is indicative of the presence of a large deep. This is consistent with the wide extension in which small outcrops of igneous rocks are found in the study area (Fig. 3), as well as the widespread poly-metallic lodes related to the gabbro reported by Lopez-Ciriano et al. (1997). On the other hand, since there is another anomaly with shorter wavelength and high intensity overlapping the previous anomaly, this is clearly indicative of the presence of complex source near the surface with high remanence and susceptibility values, probably formed by at least two different bodies with different magnetic properties.

Both the Modelling of the Anomaly observed at Surface (MAS) and the Modelling Anomaly obtained with the Upward Continuation method to 3000 m elevation (MAUC) have been carried out. The observed anomaly can be reproduced by two causative bodies, a large one at depth (numbered 1 in Fig. 15A, B) from which a shallower, sub-vertical body ( 2 in Fig. 15A, B) that connects with surface bodies (numbered 3, 4 and 5 in Fig. 15A, B) is derived. Both deep bodies have the same remanence and susceptibility values.

In detail, bodies 1 and 2 generates a small contribution with low intensity and high wavelength in the MAS (Fig. 15B), being the cause of the relative minimum and maximum observed in the northern and southern sectors, respectively. However, these bodies are the cause of most part of the anomaly in the MAUC (Fig. 15E).

Conversely, surface bodies barely contribute to the MAUC (Fig. 15F), but are the cause of the most of the 
Magnetic Surface Anomaly

A
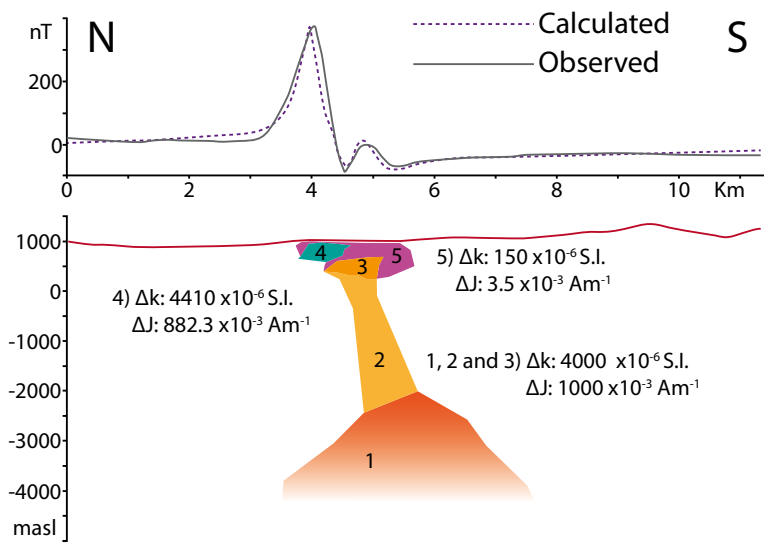

C
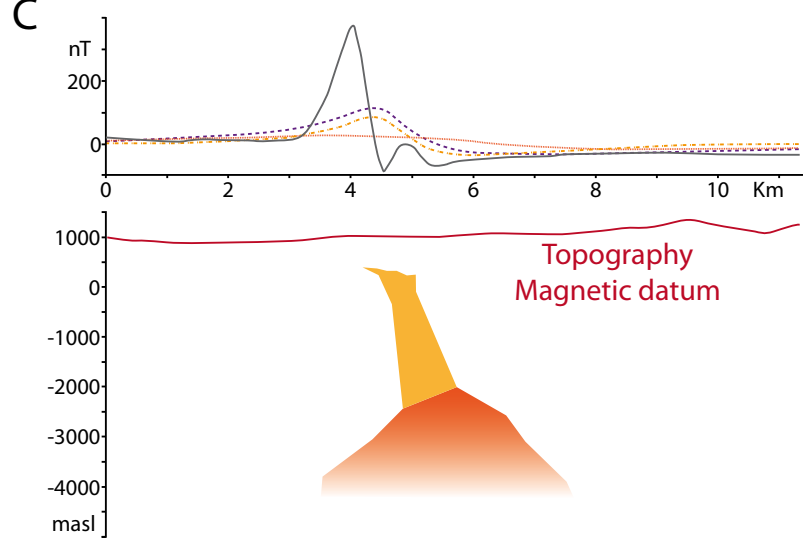

$\mathrm{E}$
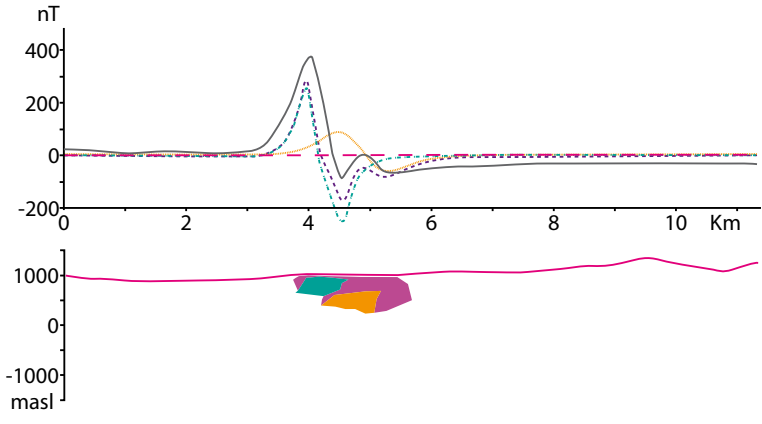

\section{Upward Continuation}

B
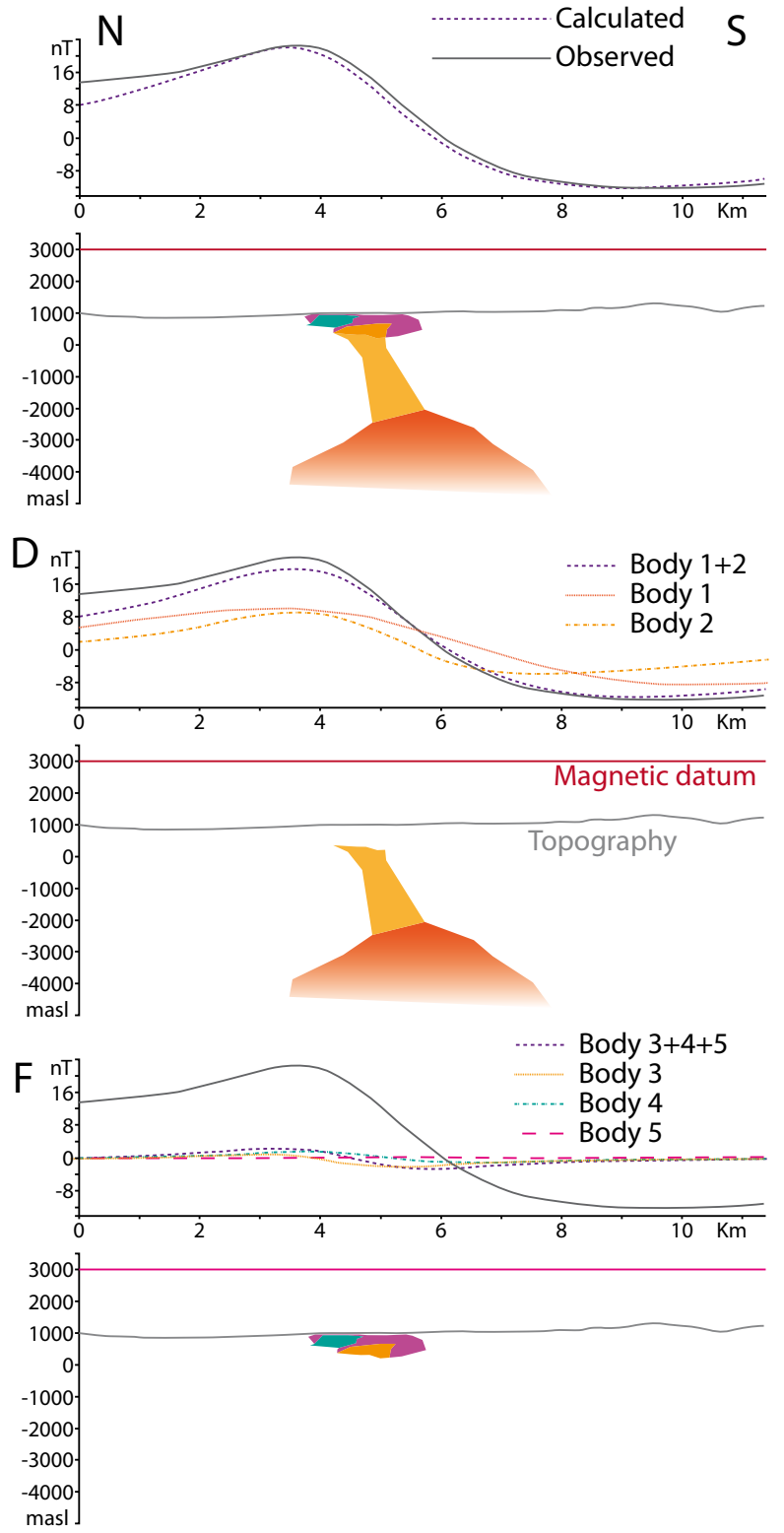

FIGURE 15. A and B) Synthetic modelling of the surface anomaly (MSA) and the anomaly at 3000m elevation (MAUC). C and D) Height of deep bodies together, and separately. E and F) Height of surface bodies together and separately.

anomaly in the MAS, generating a complex pattern with high intensity and low wavelength. More specifically, this complex pattern can be separated into a main anomaly caused by body 4 (Fig. 15C), and another anomaly generated by body 3 (Fig. 15C), slightly shifted toward the $\mathrm{S}$.

Body 5 (Figs. 15C,F), with remanence and susceptibility values similar to those of the measured samples, contributes very little to the anomaly. It may represent the outer part of the igneous body, affected to a greater extent by alteration processes.
In summary, the system is characterized by a main deep body (Body 1), that constitutes the magma reservoir. This body is connected through a feeding system (body 2) with a surface bodies of dolerites (bodies 3 and 4) with a significant amount of altered igneous rocks (body 5 ).

In this model, $\Delta \mathrm{J}$ values on the order of $0.1-1 \mathrm{Am}^{-1}$ and $\Delta \mathrm{k}$ values between $300-4500 \times 10^{-6}$ S.I. (Table 3), similar to measurements by Van der Voo (1967) in the Permian igneous rocks of Atienza (Fig. 16), were considered. These values represent relative values in regard to the background, with $\mathbf{J}$ 


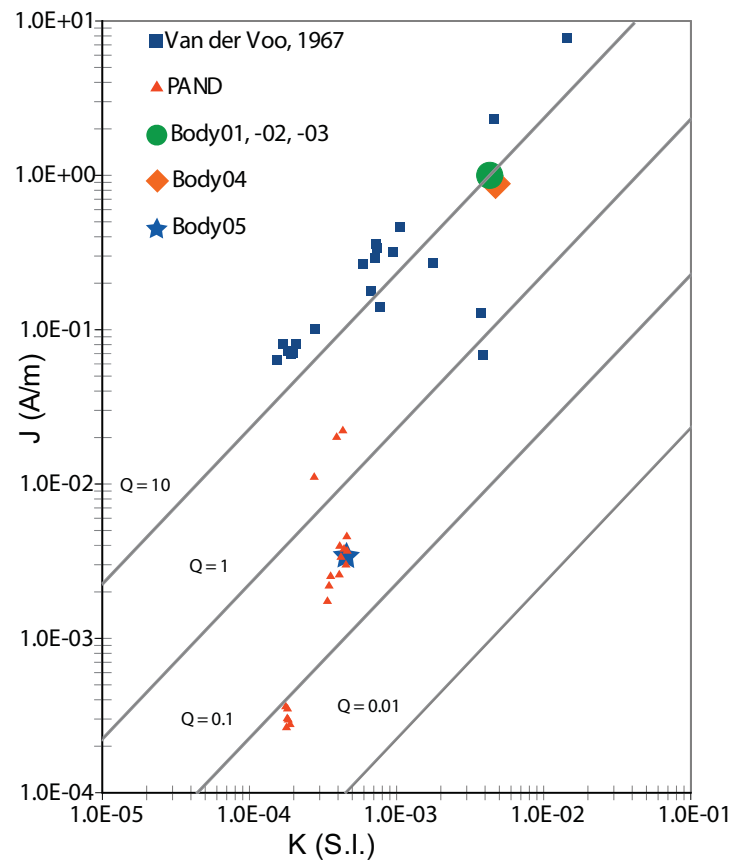

FIGURE $16 \mathrm{~J}$-k graphic showing the analysed samples (PAND, see Figure 9), the samples from Van der Voo (1997) and the bodies used in the modelling (Bodies 1 to 4). Koenigsberger ratios are also shown.

negligible values and $\mathrm{k}$ values of approximately $200-300 \times 10^{-}$ ${ }^{6}$ S.I. Since the magnetic anomaly is located in the southern limb of a post-remagnetisation syncline, declination/ inclination values from $177^{\circ}-32^{\circ}$ to $177^{\circ} /-10^{\circ}$ (mean of PAND-03 and PAND-04) were considered (Table 3).

\section{Application to other anomalies in the Iberian Chain}

The reliable structural control in the surroundings of the LMA and forward modelling shown in this work allow to hypothesize that the main causative body for this anomaly must be an igneous intrusion probably linked to normal faults post-dating the main Variscan orogenic stage. The presence of igneous rocks with reverse magnetic remanence in the subsurface is the easiest way to explain the reverse dipolar character of this anomaly. The contradictory and strongly varying magnetic properties of Permian igneous rocks exposed at surface are indicative of alteration at the top and marginal areas of this body, and therefore there must be fresh rocks below the surface with higher remanence and susceptibility values.

Considering the regional scale, there is a coincidence between reverse dipolar magnetic anomalies and large igneous bodies of Permian age (LMA, AMA) in the Iberian Chain. The relatively homogeneous properties of the host rocks, allow to extend the interpretation proposed in this work to the stronger anomaly located in the Atienza area, where Koenigsberger ratios are considerably higher (Van der Voo, 1967), probably due to lower alteration and the larger dimensions of the igneous body. However, more detailed structural analysis of the Variscan structures is necessary to check this hypothesis.

\section{CONCLUSIONS}

The aeromagnetic map of the Iberian Peninsula shows some reverse, dipolar magnetic anomalies. Specifically, the Atienza and Loscos magnetic anomalies coincide with outcrops of Permian igneous rocks.

In detail, the Loscos magnetic anomaly shows a complex pattern resulting from the overlap of two anomalies with different wavelength and intensity, which can be interpreted as the result of two heterogeneous source bodies located at different depths: i) a medium-sized gabbroic intrusion located at around $5 \mathrm{~km}$ depth connected to shallower levels with ii) subvolcanic intrusions (diorites) close to the surface.

Materials collected at surface show properties a priori not compatible with the magnetic anomaly, because of their low susceptibility and remanence values. Only PAND-04 (collected in a microgabbro intrusion) presents features consistent with this anomaly but with low remanence, possibly due to both weathering and hydrothermal alteration and primary heterogeneities as causative of inhomogeneities in the rock.

The complexity of the magnetic anomaly map and the $2.5 \mathrm{D}$ models are indicative of the presence of a heterogeneous body at depth. Its reverse remanence, acquired during the Kiaman period of reverse polarity, can be invoked as the cause of the magnetic anomaly.

Other reverse magnetic anomalies in the Iberian Chain, such as the one located in Atienza, may have the same origin as the one studied here.

\section{ACKNOWLEDGMENTS}

The authors acknowledge the financial support for this research provided by the Geotransfer Research Group (Aragón Government) and the use of Servicio General de Apoyo a la Investigación-SAI, Universidad de Zaragoza. The authors thank help from projects CGL2009-10840 and CGL2012-38481 of the Ministerio de Economía y Competitividad and European Union ERDF funds. The authors also acknowledge the constructive revisions, comments and suggestion from Isabel Blanco and an anonymous reviewer.

\section{REFERENCES}

Ardizone, J., Mezcua, J., Socías, I., 1989. Mapa aeromagnético de la España Peninsular. Madrid, Instituto Geográfico Nacional. 
Arthaud, F., Matte, P., 1977. Late Paleozoic strike-slip faulting in southern Europe and northern Africa: result of a rift-lateral shear zone between Appalachians and the Urals. Geological Society of American Bulletin, 88, 1305-1320.

Ayarza, P., Martínez-Catalán, J.R., 2007. Potential field constraints on the deep structure of the Lugo gneiss dome (NW Spain). Tectonophysics, 439, 67-87.

Calvín-Ballester, P., Casas-Sainz, A., 2014. Folded Variscan thrust in the Herrera Unit of the Iberian Range (NE Spain). In: Bastida, F., Llana-Fúnez, S., Marcos, A. (eds.). Deformation Structures and Processes within the Continental Crust. London, Geological Society, 394 (Special Publications), 39-52.

Carls, P., 1983. La Zona Asturoccidental-Leonesa en Aragón y el Macizo del Ebro como prolongación del Macizo Cantábrico. Instituto Geológico y Minero de España, 3, 11-32.

Carrancho, A., Villalaín, J.J., 2011. Different mechanisms of magnetization recorded in experimental fires: archaeomagnetic implications. Earth and Planetary Science Letters, 312, 176-187.

Casas, A., Keary, P., Rivero, L., Adam, C.R., 1997. Gravity anomaly map of the Pyrenean region and a comparison of the deep structure of the western and eastern Pyrenees. Earth and Planetary Science Lettters, 150, 65-78.

Conte, J.C., Gascón, F., Lago, M., Carls, P., 1987. Materiales stephano $\square$ pérmicos en la fosa de Fombuena (provincia de Zaragoza). Boletín Geológico y Minero, XCVIII-IV, 460470.

Cortés-Gracia, A.L., Casas-Sainz, A.M., 1996. Deformación alpina de zócalo y cobertera en el borde norte de la Cordillera Ibérica (Cubeta de Azuara-Sierra de Herrera). Revista de la Sociedad Geológica de España, 9, 51-66.

De Vicente, G., Vegas, R., Muñoz-Martín, A., Van Wees, J.D., Casas-Sainz, A., Sopeña, A., Sánchez-Moya, Y., Arche, A., López-Gómez, J., Olaiz, A. Fernández-Lozano, J., 2009. Oblique strain partitioning and transpression on an inverted rift: The Castilian Branch of the Iberian Chain. Tectonophysics, 470, 224-242.

Del Río, P., Casas, A., Villalaín, J.J., Mochales, T., Soto, R., Oliva-Urcía., B., 2013. Interpretation of gravimetric and magnetic anomalies in the Cameros Basin (North Spain): combination of deep and shallow sources. Studia Geophysica et Geodetica, 57, 442-459.

Gibbons, W., Moreno, T., 2002. The geology of Spain. London, Geological Society, 650pp.

Gómez-Ortiz, D., Tejero-López, R., Babin-Vich, R., RivasPonce, A., 2005. Crustal density structure in the Spanish Central System derived from gravity data analysis (Central Spain). Tectonophysics, 403, 131-149.

Gozalo, R., Liñan, E., 1988. Los materiales hercínicos de la Cordillera Ibérica en el contexto del Macizo Ibérico. Estudios geológicos, 44, 399-404.

Gradstein, F.M., Ogg, J.G., 2004. Geologic Time Scale 2004 why, how, and where next! Lethaia, 37, 175-181.

Hammer, S., 1939. Terrain corrections for gravimeter stations. Geophysics, 4, 184-94.
Hernando, S., Schott, J.J., Thuizat, R., Montigny, R., 1980. Age des andésites et des sédiments interstratifiés de la région d'Atienza (Espagne): Etude stratigraphique, géochronologique et paléomagnétique. Sciences Géologiques Bulletin, 33, 119-128.

Socías, I., Mezcua, J., 2002. Anomalías Magnéticas de la Península Ibérica. Instituto Geográfico Nacional, Spain, 1 map.

Hinze, W.J., Aiken, C., Brozena, J., Coakley, B., Dater, D., Flanagan, G., Forsberg, R., Hidenbrand, T., Keller, R., Kellogg, J., Kucks, R., Li, X., Mainville, A., Morin, R., Pilkington, M., Plouff, D., Ravat, D., Roman, D., UrritiaFucugauchi, J., Véronneau, M., Webring, M., Winester, D., 2005. New standards for reducing gravity data: The North American gravity database. Geophysics, 50, J25-J32.

Irving, E., Parry, L.G., 1963. The Magnetism of Some Permian Rocks from New South Wales. Geophysical Journal, 7, 395-411.

Kristjansson, L., Jonsson, G., 2007. Paleomagnetism and magnetic anomalies in Iceland. Journal of Geodynamics, 43, 30-54.

LaFehr, T.R., 1991. Standardization in gravity reduction. Geophysics, 56, 1170-1178.

Lago, M., Pocoví, A., Zachmann, D., Arranz, E., Carls, P., Torres, J.A., Vaquer, R., 1991. Comparación preliminar de las manifestaciones magmáticas, calco-alcalinas y stephaniense $\square$ pérmicas, de la Cadena Ibérica. Cuadernos do Laboratorio Xeolóxico de Laxe, 16, 95-107.

Lago, M., Arranz, E., Pocoví, A., Galé, C., Gil-Imaz, A., 2004. Lower Permian magmatism of the Iberian Chain, Central Spain, and its relationship to extensional tectonics. In: Davies, G., Heeremans, M., Larsen, B., Neumann, E., Timmerman, M., Wilson, M. (eds.). Permo $\square$ Carboniferous Magmatism and Rifting in Europe. London, Geological Society, 223 (Special Publications), 465-491.

Lago, M., Gil, A., Arranz, E., Galé, C., Pocoví, A., 2005. Magmatism in the intracratonic Central Iberian basins during the Permian: Palaeonvironmental consequences. Palaeogeography, Palaeoclimatology, Palaeoecology, 229, 83-103,

Lopez-Ciriano, A., Yuste-Oliete, A., Fernández-Nieto, C., 1997. Aspectos estructurales y mineralógicos de los filones polimetálicos de Loscos (norte de Teruel, Cadena Ibérica Oriental). Boletín de la Sociedad Española de Mineralogía, 20, 89-114.

Louro, V.H.A., Mantovani, M.S.M., 2012. 3D inversion and modeling of magnetic and gravimetric data characterizing the geophysical anomaly source in Pratinha I in the southeast of Brazil. Journal of Applied Geophysics, 80, 110-120.

Moritz, H., 1980, Geodetic Reference System 1980. Journal of Geodesy, 54, 395-405.

Ortiz-Alemán, C., Urrutia-Fucugauchi, J., 2010. Aeromagnetic anomaly modeling of central zone structure and magnetic sources in the Chicxulub crater. Physics of the Earth and Planetary Interiors, 179, 127-138. 
Osete, M.L., Rey, D., Villalaín, J.J., Juárez, M.T., 1997. The Late Carboniferous to Late Triassic segment of the apparent polar wander path of Iberia. Geologie en Mijbouw, 76, 105-119.

Pedreira, D., Pulgar, J.A., Gallart, J., Torné, M., 2007. Threedimensional gravity and magnetic modeling of crustal indentation and wedging in the western Pyrenees-Cantabrian Mountains. Journal of Geophysical Research, 112, B12405.

Ribeiro, V.B., Louro, V.H.A., Mantovani, M.S.M., 2013. 3D inversion of magnetic data of grouped anomalies- Study applied to São José intrusions in Mato Grosso, Brazil. Journal of Applied Geophysics, 93, 67-76.

Rybakov, M., Goldshmidt, V., Hall, J.K., Ben-Avraham, Z., Lazar, M., 2011. New insights into the sources of magnetic anomalies in the Levant. Russian Geology and Geophysics, 52, 377-397.

Salas, R., Casas, A., 1993. Mesozoic extensional tectonics, stratigraphy and crustal evolution during the Alpine cycle of the eastern Iberian basin. Tectonophysics, 228, 33-35.
Santolaria, P., Casas, A.M., Soto, R., Casas, A., 2012. Análisis de las anomalías gravimétricas de la terminación suroccidental de la Unidad Surpirenaica Central. Geotemas, 13, 445-448.

Urrutia-Fucugauchi, J., Trigo-Huesca, A., Pérez-Cruz, L., 2012. Magnetic links among lava flows, tuffs and the underground plumbing System in a monogenetic volcano, derived from magnetic and paleomagnetic studies. Physics of the Earth and Planetary Interiors, 212, 10-18.

Van der Voo, R., 1967. The rotation of Spain: paleomagnetic evidence from the Spanish Meseta. Palaeogeography, Palaeoclimatology, Palaeoecology, 3, 393-416.

Vera, J.A., 2004. Geología de España. Madrid, Sociadad Geológica de España-Instituto Geológico y Minero de España, 884pp.

Whitney, D.L., Evans, B., 2010. Abbreviations for names of rockforming minerals. American Mineralogist, 95, 185-187.

\footnotetext{
Manuscript received May 2013

revision accepted July 2014;

published Online July 2014.
} 